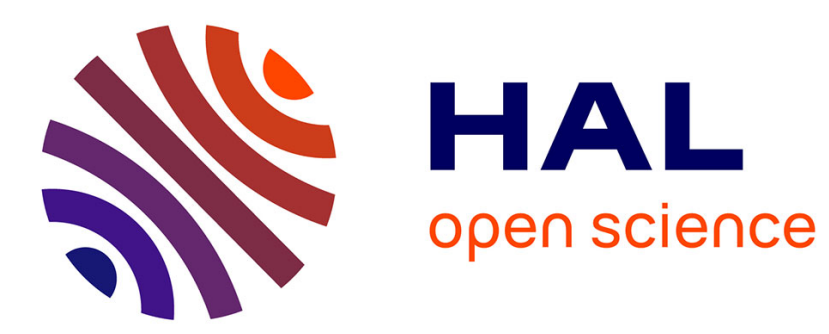

\title{
The Contribution of Douglass North to New Institutional Economics
}

Claude Ménard, Mary M. Shirley

\section{To cite this version:}

Claude Ménard, Mary M. Shirley. The Contribution of Douglass North to New Institutional Economics. 2011. halshs-00624297

\section{HAL Id: halshs-00624297 https://shs.hal.science/halshs-00624297}

Preprint submitted on 22 Sep 2011

HAL is a multi-disciplinary open access archive for the deposit and dissemination of scientific research documents, whether they are published or not. The documents may come from teaching and research institutions in France or abroad, or from public or private research centers.
L'archive ouverte pluridisciplinaire HAL, est destinée au dépôt et à la diffusion de documents scientifiques de niveau recherche, publiés ou non, émanant des établissements d'enseignement et de recherche français ou étrangers, des laboratoires publics ou privés. 
DRAFT for editors

June 21, 2011

\title{
The Contribution of Douglass North to New Institutional Economics
}

\author{
By \\ Claude Ménard and Mary M. Shirley ${ }^{1}$ \\ Forthcoming in: \\ Economic Institutions, Rights, Growth, and Sustainability: \\ The Legacy of Douglass North. \\ Cambridge University Press: Cambridge. \\ Chap. 1
}

\begin{abstract}
Douglass North, along with Ronald Coase and Oliver Williamson, transformed the early intuitions of new institutional economics into powerful conceptual and analytical tools that spawned a robust base of empirical research. NIE arose in response to questions not well explained by standard neoclassical models, such as make or buy and why rich or poor? Today NIE is a success story by many measures: four Nobel laureates in under 20 years, increasing penetration of mainstream journals, and significant impact on major policy debates from anti-trust law to development aid. This paper provides a succinct overview of North's evolving ideas about institutions and explains how North's work shaped the emerging field of new institutional economics and had a potent impact on economics and the social sciences more broadly. North provides a powerful example of how persistent and well placed confidence and hard work can productively transform the status quo. North's influence continues strong and his enthusiasm for exploring new frontiers and cooperating across artificial academic boundaries has never waned.
\end{abstract}

\footnotetext{
${ }^{1}$ Centre d'Economie de la Sorbonne at the University of Paris -Pantheon Sorbonne (Ménard) and Ronald Coase Institute (Ménard and Shirley). Both participated actively to the foundation and are past presidents of the International Society for New Institutional Economics
} 


\section{Introduction}

New Institutional Economics (NIE) began to take shape around some relatively vague intuitions only in the 1970s, yet today it counts a number of successes. To mention a few: four Nobel laureates in under 20 years; significant impacts on major policy debates ranging from anti-trust law to development aid; increasing penetration of mainstream journals; and a large and growing body of adherents, research, and data. Many actors were important to this successful evolution; in another paper we have focused on three in particular. Ronald Coase, Douglass North and Oliver Williamson transformed early intuitions about institutions into powerful conceptual and analytical tools, spawning a vigorous base of empirical research.

Today's robust institutionalization of NIE is especially remarkable when we consider that from the beginning it was divided into distinct schools of thought. One school of thought is identified with Coase and Williamson, and analyzes property rights and contracts at the firm level; while another, identified with Douglass North, analyzes broader institutional environments and the role of the state. ${ }^{2}$ This paper focuses on the contribution of Douglass North and the school of thought associated with his work to the development and institutionalization of NIE. The paper's main contribution is a succinct overview of North's evolving ideas about institutions and an explanation of how North's

\footnotetext{
${ }^{2}$ There are a number of other schools of thought that developed simultaneously and are closely associated with or even part of NIE that we do not have space to cover adequately here. These include, for example, the theories of Mancur Olson, public choice theory and the work of Buchanan and Tullock, and the work of positive political scientists such as Ken Shepsle and Barry Weingast. Closely associated with NIE is the work of Harold Demsetz, in the continuation of the property rights approach. However, when it comes to the history of how ISNIE was born and develop, we think that the two branches on which we focus here led the way and represent the dominant group of participants. Our Handbook of New Institutional Economics (2005) includes a relatively wide spectrum of the contributors to NIE, including the four Nobel laureates, although some other major names (e.g., Barzel or Demsetz) are missing
} 
work shaped the emerging field of new institutional economics with important repercussions for economics and the social sciences more broadly. For example, North's research changed many economists' view of development from a process of growth spurred by new technology and capital accumulation to a dynamic process of institutional change. The paper offers a valuable lesson of how persistent and well placed confidence and hard work can productively transform the status quo.

New institutional economics stresses rules and norms, and accepts diversity in disciplines and methodologies. NIE accepts much of the standard neoclassical paradigm, although with important exceptions that give NIE its revolutionary character. ${ }^{3}$ As we explain later, NIE arose in response to two puzzles not well explained by the standard neoclassical paradigm: the decision to make, to buy, or to look for alternative organizational arrangements and the explanation for why some countries are rich and some countries are poor.

The next section of this paper summarizes how the key concepts that underlie all institutional analysis were formulated in response to the failings of the standard paradigm. Section III then traces the special contribution of Douglass North to the transformation of NIE from early ideas to analytical tools, analyzing the evolution of his ideas on institutions, and Section IV describes the dissemination of NIE in general and North's ideas in particular. Section V discusses the challenges for future research. We conclude with a brief discussion of the threat that growing mainstream acceptance will erode NIE's revolutionary character, creative focus, and interdisciplinary. How best can institutionalists meet this threat? The remarkable scholarly life of Douglass North offers a

\footnotetext{
${ }^{3}$ In Ménard and Shirley (2010) we examine these exceptions in detail.
} 
stellar example of how creativity, insight, and innovation can be preserved and strengthened over the course of many decades.

\section{The intellectual origins of $\mathrm{NIE}^{4}$}

Virginia Woolf once asserted that "on or about December 1910 human character changed." (Woolf, 1928, p.4) We cannot be so bold in determining when economics changed, ${ }^{5}$ but we can date the origins of the changes introduced by NIE. They emerged from the confluence of several major contributions: two pioneering papers from Ronald Coase, "The Nature of the Firm" (1937/1988b) and "The Problem of Social Costs" (1960/1988a), two defining books -- North and Davis on Institutional Change and American Economic Growth (1970) and North and Thomas on The Rise of the Western World (1973), and the land mark book Markets and Hierarchies (1975) by Williamson. Although there were predecessors, as there are with all schools of economics, these contributions laid the foundation for the transformation of NIE's initial intuitions into a useful analytical apparatus.

As we mentioned, new institutional economics arose in response to puzzles not well explained by mainstream economics, notably: why make or buy? Why rich or poor? The first puzzle was to explain the organization of economic activity into firms, markets, bureaus, franchises, and other modes of organization, to understand what went on inside the firm, and to explain firm decisions about mergers versus contacts. The second puzzle was to explain the disparity in the performance of economies and the persistence of these disparities despite countless efforts at reform and decades of foreign aid and advice.

\footnotetext{
${ }^{4}$ This section draws from Menard and Shirley (2010).

${ }^{5}$ Although we might note that Ronald Coase was born in December 1910.
} 
The standard neoclassical paradigm viewed the economic system as adjusting supply to demand and production to consumption automatically, under the coordination of the price mechanism. Neoclassical economists long treated the firm as a black box, a production function that turned inputs into outputs, responding to changes in relative prices and available resources in ways that maximize profits. This system worked under certain simplifying assumptions that troubled the founders of NIE, such as the assumptions that information is perfect, individuals are rational wealth-maximizers with stable preferences, and exchange is instantaneous and costless. New institutionalists also questioned mainstream assumptions that different rates of development were purely the result of different endowments of resources and human capital or of different rates of investment and adoption of new technologies. Another puzzle that particularly concerned North was the nature of the state; why don't political markets function like economic markets? Under what circumstances do states protect property rights even when they have unchallenged power to expropriate property and subjugate individuals?

NIE's answers to these questions rest on three key concepts - transaction costs, property rights and contracts. These concepts became the "golden triangle" of NIE and, combined with NIE's increasingly radical behavioral assumptions (e.g., North 2005), progressively structured NIE's two leading schools. Let us consider briefly the origin of those three key concepts.

The concept of transaction cost arose when Ronald Coase first challenged the standard description of the economy as an automatic process that equilibrates supply with demand by means of the price mechanism in his 1937 paper "The Nature of the Firm." 
Coase asked, why are there firms $?^{6}$ The answer, as he later described it, was that “...although production could be carried out in a completely decentralized way by means of contract between individuals, the fact that it costs something to enter into these transactions means that firms will emerge to organize what would otherwise be market transactions whenever their costs were less than the costs of carrying out the transactions through the market." (Coase, 1988a, p. 7) In the market a would-be trader must find someone with whom to trade, determine price and quality, reach an agreement between buyer and seller, and monitor and enforce that agreement. By eliminating the need for bargains among the many owners of the factors of production, a firm can sometimes reduce these transaction costs (see Coase 1960).

Steven Cheung later enriched the idea that a firm would lower transaction costs whenever: discovering a price through the market required numerous transactions or information about many different components of a product; measurement of attributes that change frequently, vary greatly, or may not be conveniently stipulated in advance; and specifying different contributions of inputs that cannot be easily separated (Cheung, $1983) .^{7}$

Williamson operationalized the concept of transaction costs by asking: what are the specific factors that determine the choice between market and firm? How does a firm decide whether to make, to buy, or to rely on alternative arrangements such as franchising, joint ventures, strategic alliances and so forth? His answers focused in

\footnotetext{
${ }^{6}$ At about the same time that Coase wrote his paper, Commons (1934, p. 4) introduced the idea that “...the ultimate unit of activity...must contain in itself the three principles of conflict, mutuality, and order. This unit is a transaction." Coase was apparently unaware of this development, but later on Williamson (1975, p.6, 1996, p. 7) integrated it into his approach to transaction costs.

${ }^{7}$ Cheung also showed how transaction costs affect contractual arrangement in different sectors, most notably agriculture $(1969,1973)$.
} 
particular on the role of asset specificity, uncertainty, and the frequency of transacting, something we explore in greater detail in another paper (Menard and Shirley, 2010).

In later work Coase argued that transaction costs profoundly influence not just individual firms but the size and activities of the entire economy. "If the costs of making an exchange are greater than the gains which that exchange would bring, that exchange would not take place and the greater production that would flow from specialization would not be realized. In this way transaction costs affect not only contractual arrangements but also what goods and services are produced." (Coase 1992, p. 716) In the continuation of this idea, North used the concept of transaction costs to address the question: why are some countries rich and some countries poor?

In particular, North extended the concept of transaction costs to explain the state and some of its fundamental characteristics (1990b). Political markets are more prone to inefficiency than economic markets. The cost of measuring and enforcing agreements is higher in political markets, North argued, because what is being exchanged - promises for votes - is inherently difficult to measure. Voters may find it hard to judge if the actions of their representatives produce outcomes that favor voter interests; voters may not even know what their interests are under certain policy choices. And voter ability to judge their representatives' effectiveness is clouded by beliefs: representatives do not just make policy promises to their constituents, they also sell themselves on the basis of ideological frameworks that appeal to voters' preferences and prejudices. Competition, which plays a powerful enforcement role in economic markets, is far weaker in political markets, where representatives can be held accountable only in infrequent elections. 
Non-democratic political markets lacking even electoral competition operate with far less transparency, so political transaction costs are likely to be even higher.

NIE's second central concept is property rights. Standard neoclassical economics assumed that what people trade are physical commodities, but Coase argued in his paper "The Federal Communications Commission" that what they really trade are rights -- the rights to perform certain actions -- and that those rights with their duties and privileges are established by the legal system (Coase 1959). This view of property rights was further developed by Armen Alchian in a contribution initially published in Il Politico in 1965, where he defined property rights as a set of rights to take permissible actions to use, transfer, or otherwise exploit or enjoy property. These rights are sometimes enforced by law but more often are enforced by etiquette, social custom, and social ostracism. ${ }^{8}$

Unlike standard neoclassical economics, which assumes contracts are complete and costlessly enforceable through the judicial system, Williamson's work on contracts also implied that property rights would be vulnerable to opportunistic predation and that legal systems are usually a more costly remedy for disputes than private ordering. North focused on how property rights and their enforcement affect the ways societies develop and differ. North contrasted the robust property rights of powerful elites with the vulnerable or absent rights of non-elites in societies where non-elites have little access to legal or political remedies.

Ostrom further expanded and enhanced our understanding of property rights with her work on alternative ways to organize common property resources such as irrigation systems or fishing grounds to those postulated by mainstream economics: private

\footnotetext{
${ }^{8}$ Demsetz (1967) substantiated Alchian's view in his controversial analysis of the emergence of private property rights among the 'Montagnais', a tribe of Northeastern Canada where he argued that property rights arise when it becomes economically beneficial.
} 
ownership or state regulation. Ostrom argued that under certain circumstances governance by local user groups is superior to poorly defined and enforced private property rights (leading to the tragedy of the commons), as well as to government regulation or state ownership. Through meticulous and extensive field work Ostrom showed that where the boundaries of the users and the resources are clear, monitoring and enforcement by small, tightly-knit groups with strong social norms and procedures for making rules and enforcing sanctions produces superior outcomes. She also tested her hypotheses thoroughly in laboratory experiments. Ostrom's evolving theoretical framework provided a foundation for scientific analysis of highly complex and heterogeneous institutions through carefully designed comparative microanalytics.

NIE's third core concept is contract. In the standard neoclassical paradigm, contracts are agreements between parties that are (1) perfectly enforced and (2) perfectly complete. Once again the concept of contract was progressively developed along different paths by the two main branches of NIE. Williamson stressed the issue of incomplete contracts as early as 1971 in a paper on vertical integration. In his formulation, opportunism -- the idea that parties to an exchange may defect from the spirit of cooperation when the stakes are high -- overturned neoclassical behavioral assumptions that ignored these human traits. To Williamson, a contract is "an agreement between a buyer and a supplier in which the terms of exchange are defined by a triple: price, asset specificity, and safeguards" (ital. from OEW, 1996, p. 377). Williamson's approach to contracts became central to NIE's analysis of governance, and, as emphasized by the Nobel Committee in 2009 , became the source of many successful 
empirical investigations, operationalizing the Coasian approach in micro-economics and industrial organization.

The 'Northean' branch emphasized early on the key role of contract enforcement and the institutions it requires, particularly the polity (North, 1981, chap. 4). ${ }^{9}$ Contract enforcement and especially the role of coercion in protecting property rights and individual rights later developed into a theory of its own. North highlighted the trade off between the high cost of private protection of property using private police, private armies and the like, versus the risk of state protection of property, which might reduce private costs but invite state encroachment on rights (see North et al., 2009; and also North and Weingast, 1989; Weingast, 1993; Greif, 2005). The risk of state predation led North, Weingast, and others to emphasize ways the state might credibly commit to respect private property rights, a theme that united the two branches of NIE.

Transaction costs, property rights, and contracts are not the only concepts developed by NIE, but we argue that they encapsulate its core and make its paradigm distinctive. One reason why NIE differs radically from the orthodox approach is because these core concepts reject standard neoclassical assumptions of perfect information, perfect rationality, and zero transaction costs.

\section{From early ideas to analytical tools: The Contribution of Douglass North}

In the late 1960's and early 1970's, these early ideas about transaction costs, property rights and contracts were already evolving into the core concepts of what Williamson christened New Institutional Economics (Williamson, 1975, chap.1). A research program progressively blossomed challenging some of the main assumptions of

\footnotetext{
${ }^{9}$ See also the influence of Buchanan \& Tullock (1962) on North; and Buchanan (1975) on Williamson. Barzel's contribution to the analysis of property rights and the violence of the state also deserves mention here (e.g., 1989).
} 
standard neoclassical economics. As we have mentioned, this program developed almost simultaneously along two branches. In another paper we consider both branches and their interactions, but here we focus on the contribution of Douglass North to the branch that we call institutional analysis.

Douglass North's earliest intellectual roots were as a Marxist when he was an undergraduate at the University of California at Berkeley (See Figure 1). Another early influence was World War II: North had to think profoundly about violence and societies when he decided to join the merchant marine because, as he put it, "I did not want to kill people." Later he was exposed to the ideas of Joseph Schumpeter through the entrepreneurial school of Arthur Cole at Harvard. Schumpeter had a strong influence on North's thinking, as did his interactions with the economists he met when he spent a year at the NBER in the mid-1950's, including Solomon Fabricant and Simon Kuznets.

In the later 1950's and early 1960's North became a leader in the first efforts to apply economic theory and quantitative methods to history and in the process became a founder of the new field of cliometrics (another subject in its own right and beyond the scope of this paper). His emphasis on institutions began later and developed gradually. The rest of this section summarizes some of the main milestones in North's institutional theories, which we illustrate in Figure 2.

In his 1961 and 1966 books on economic history North largely followed the standard model. For instance, he attributed economic growth to three factors: technology, human capital, and efficient economic organization, giving primacy to technological change (North, 1961, 1966). But North was beginning to question the applicability of mainstream economics in the 1960's when he turned to study European history. 
Increasingly he concluded that the tools of neoclassical economics "were not up to the task of explaining the kind of fundamental societal change that had characterized European economies from medieval times onward" (North 1993, p. 3).

North departed noticeably from a strictly neoclassical approach in his famous 1968 paper in the Journal of Political Economy (one of the most quoted research works in economic history according to the Nobel committee). This paper explains the reasons for productivity gains in ocean shipping since 1600. Prior to this paper, as North puts it, "Among economic historians, technological change has always held the pre-eminent position as a source of economic growth" (North 1993, p. 953). North's 1968 paper knocked technology off its throne.

The genesis of the paper was exceptionally hands on. While pondering the puzzle of productivity gains in shipping, North toured a maritime museum in the Netherlands. North noticed that the ship models did not display any major technology improvements, but did carry fewer and fewer armaments. He went home and built models of ships from historical kits to confirm his observations. North knew first hand from his experience in the merchant marine the importance of weight and labor costs to productivity in ocean shipping, and the paper shows how a decline in piracy and privateering permitted ships to reduce both heavy armaments and manpower and also lowered insurance costs. Additional key factors in productivity improvements were the development of bigger markets and the aggregation of goods in fewer ports, which allowed ships to transport goods in both directions and reduced turn around time in port. Through a combination of practical experience, keen observation, and meticulous research, North opened a new perspective on productivity improvement. 
North's 1971 book with Lance Davis, Institutional Change and American Economic Growth (North 1971) continued to diminish the priority assigned to technology as the explanation for growth. North and Davis also specified a theory of institutional change, which they applied to facets of US economic history. Despite its unorthodoxy, the book still showed strong neoclassical roots, especially in its hypothesis that institutional innovation occurs when the expected net gains exceed the expected costs.

North's 1973 book with Robert Paul Thomas, The Rise of the Western World. A New Economic History similarly moved toward giving organizational and institutional change a greater role in determining growth. North and Thomas asserted that "efficient economic organization is the key to growth" and efficient economic organization entails "the establishment of institutional arrangements and property rights that create an incentive to channel individual economic effort into activities that bring the private rate of return close to the social rate of return." (North and Thomas 1973, p. I) The book argued that it was new institutional arrangements such as written contracts enforced by courts that were largely responsible for successful European economic development because they enabled units "to realize economies of scale (joint stock companies, corporations), to encourage innovation (prizes, patent laws), to improve the efficiency of factor markets (enclosures, bills of exchange, the abolition of serfdom), or to reduce market imperfections (insurance companies)" (Ibid., p. 5-6). Yet the North and Thomas framework still showed neoclassical roots. For instance, it still assumed that institutions changed when the net benefit from change outweighed the cost, although North and Thomas did document that the fiscal benefits to government sometimes lead the state to protect inefficient property rights for a very long time, as in Spain. 
Increasingly North began to ask how these efficiency assumptions could be true when for centuries most countries have suffered under persistently inefficient institutions causing persistently poor economic performance. He sought a more realistic explanation for why societies choose the institutions they have and why they choose to change them. In his breakthrough book, Structure and Change in Economic History (North 1981) he abandoned the assumption that institutions were efficient. In this book he also introduced the role of ideology in fostering or hindering change, foreshadowing his later interest in beliefs.

North's seminal 1990 book, Institutions, Institutional Change, and Economic Performance, went further in abandoning neoclassical assumptions about efficiency and rationality (1990a). Here North answers his persistent question about wealth and poverty as follows: "Third World countries are poor because the institutional constraints define a set of payoffs to political/economic activity that do not encourage productive activity" (Ibid, p. 110). In this book institutional change occurs when those economic or political entrepreneurs who have the bargaining strength to change institutions perceive "that they could do better by altering the existing institutional framework on some margin. But their perceptions crucially depend on both the information the entrepreneurs receive and how they process that information" (Ibid., p. 8). Their information is often incomplete, their models imperfect, and their reforms "path dependent" -- constrained by the existing set of institutions and incentives.

North began to go beyond information problems and path dependency, arguing that radical reforms are also constrained by societies' inherited belief systems. "Societies that get 'stuck' embody belief systems and institutions that fail to confront and solve new 
problems of societal complexity" (North 1994, p. 6). The sticky nature of beliefs and institutions helps explain why underdevelopment has been so persistent in most of the world and why efforts to reform by importing rules, laws, and constitutions from elsewhere have been so unsuccessful. But a new puzzle arose. If rules and norms resist change because of beliefs, than what determines beliefs? North turned to cognitive science to understand better how human's beliefs are affected by their "mental models." Human beings use mental models to explain and interpret the world, models that are shaped by their personal experiences and their inherited belief system - the belief system that they share with other members of their society. Because learning is filtered through this shared belief system, the past affects how people solve problems today (North 2005, p. 77).

Having developed an institutional framework to explain European and American history and then having adapted it to explain the history of underdevelopment, North recently joined with John Wallis and Barry Weingast to interpret all of recorded human history (North, et al. 2009). Their analysis starts ten thousand years ago when humans were still dominated by warring tribes. In some of these tribes small groups of powerful elites formed coalitions around specialists in violence who could protect non-military elites, such as traders or the clergy, and limit outsiders' access to valuable resources land, labor, capital - and valuable activities - trade, worship, education (Ibid., p. 30). Limiting non-elite access gave elites exclusive control over resources and activities that generated rents. These rents in turn motivated the elites to agree not to fight each other but to share power, creating a stable equilibrium for expanded trade and production - and 
additional rents. This equilibrium was so stable that limited access orders came to dominate most societies through most of human history; they became the "natural state."

Natural states encompasses a large and varied group; some are "fragile," tottering on the brink of chaos and war; others are "basic" with more durable and stable state organizations; and some are "mature" with many of the formal trapping of open access such as secure property rights, regular elections, and apparently open trade. But all natural states, even the mature ones, enforce property rights and rule of law only for elites, and all have institutions designed to limit access. Access is limited in basic and fragile natural states by laws and norms that allow only elites to engage in trade or to create or dominate corporations, unions, political parties, clubs, and other organizations. Non-elites may not be explicitly excluded from starting businesses or going into politics in mature natural states, but if they try they will face such high transaction costs that they will not be able to compete with elites. For example, it will be much cheaper and easier for elite-run business to get credit or government contracts because banks and state agencies are run by their cronies. Elites in natural states use the law, the state, social networks, and tradition to limit access and retain control, but that does not mean that the specific elite group that controls power and wealth never changes. To the contrary, the personalities with power and wealth change frequently through coups, revolutions, and even elections. What seldom changes are the institutions that exclude the bulk of society from access to the means of power and wealth. When non-elite groups manage to wrest control from the elites, the new insiders usually use the same exclusionary institutions to limit access for everyone outside their circle. 
Open access societies are still the exception. They only emerged recently, after the industrial revolution in Europe, and spread to the countries that now compose the developed world. They operate very differently from limited access orders; they are distinguished by shared belief systems emphasizing equality, sharing, and universal inclusion. Open access institutions ensure that the political system controls the use of violence, laws are enforced impartially, and citizens across society have access to competitive economic and political organizations at relatively low transaction costs. Not only is access open, the risks of market participation are reduced and the gains across society are shared through such means as universal education, social insurance programs, and widespread infrastructure and public goods (Ibid., p. 111).

Economic development takes on a new meaning in North, Wallis, and Weingast's framework. "In addition to capital accumulation, being developed economically entails having sophisticated economic organizations and credible enforcement of property rights and other contractual commitments. Similarly, being developed politically entails having rule of law, a constitutional setting in which all major players accept changes of power, effective legal recognition of organizational rights independently of who is in power, and state control of organized violence." (North et al. 2009, p. 3)

North, Wallis, and Weingast is the latest in North's evolving insights about how institutions explain long-run economic performance, insights that have stimulated a large body of applied research. Simultaneous with this rising interest in Northean institutional analysis, there was a rising interest in NIE more broadly, and we document both trends in our next section. 


\section{The Diffusion of NIE in General and Institutional Analysis in Particular}

North's work contributed to a general diffusion of new institutional economics, and the feedback from this expanding network also fed into his evolving theory. The diffusion of NIE was also spurred by the creation of an international society, a process in which North also played an important role.

\section{A. The Diffusion of New Institutional Economics}

During the late 1980's and early 1990's the number of researchers attracted to NIE and its influence over economics and other disciplines began to expand. Scholars increasingly cited Coase, North, and Williamson in the literature, presentations and sessions on institutional research at international conferences multiplied, and the subject attracted adherents in political science, management, law, sociology, and anthropology, among others. We can get a partial picture of this trend by looking at the increase in articles referring to NIE in refereed journals. Chart 1 shows that publications listed in Goggle Scholar with New Institutional Economics in the title grew from one in the 1970 's and 50 in the 1980's to close to 200 in the 1990's and over 400 in the 2000 's.

With the spread of articles on new institutional economics, a network of new institutionalists began to emerge. At first the network was informal and unorganized: scholars with an interest in institutions simply attended each other's presentations at meetings in economics, managerial sciences, history, political science, and other social sciences. This informal network got a boost in 1983 when Rudolf Richter began to organize, initially with Eirik Furubotn, an annual research seminar on institutions in Germany. ${ }^{10}$ All leading institutionalists attended this conference at one time or another,

\footnotetext{
${ }^{10}$ Held in Mettlach for the first two years than in Wallerfangen, under which name the seminar became known.
} 
and their contributions were published in the Journal of Institutional and Theoretical Economics.

Still, this informal network was largely sustained by sporadic and haphazard encounters of like-minded institutionalists in conference devoted to other topics. The sporadic nature of these contacts frustrated some scholars who began to discuss the creation of a more formal network in the early 1990's. In a process that we have documented in another paper (Menard and Shirley 2010), their activities led to the creation of the International Society for New Institutional Economics (ISNIE), with annual meetings that gave a large boost to the diffusion of the field.

Douglass North played a key role in the creation of ISNIE. He was highly supportive of the idea of a more formal network from the first time Claude Menard proposed it in a 1994 conference in Paris. He continued to be enthusiastic throughout the startup of the new organization, providing strong support to initiatives led by Lee and Alexandra Benham, Claude Menard, and Mary Shirley, later reinforced by John Drobak and others. North co-signed a letter with Ronald Coase inviting a large group of scholars to join the new society in October 1996. He participated actively in the early planning meetings and agreed to join the board of directors and to serve two terms (1988-2000) as the second president of the new Society (Ronald Coase was the first). He continued thereafter to lend his strong support to ISNIE as a board member and regular speaker at the meetings. As we report elsewhere (Menard and Shirley 2010), ISNIE has provided institutional scholars with a regular point of contact, attracted new adherents to NIE, and accelerated the dialogue between the two main branches and across disciplines. 


\section{B. The Diffusion of Northean Institutional Analysis}

Initially the branch of institutional analysis identified with Douglass North captured a wider audience, although Coasian-Williamsonian ideas were highly influential in specific fields, such as industrial organization, managerial science, and law and economics. ${ }^{11,12}$ We can see the spread of North's ideas in Figure 4, which shows the rise in citations of North's articles. Since most of North's most influential publications are books, this figure gives a very partial indication of his impact but it does show the strong upward trend.

North's work had an impact on a number of fields. For example, his work was one of a number of important influences shaping the direction of the new political economy. New political economy initially largely focused on the United States and democracy, voting, legislative rules, and bureaucracy, but more recently there has been an upsurge in studies analyzing a broader set of institutions and covering polities in European and developing and transitional countries. Northean institutional analysis also influenced how scholars study utilities, such as telecommunications, water, or electricity, and common pool problems and management of small communities, such as Ostrom's work. Increasingly these scholars are analyzing how broader political, constitutional, and

\footnotetext{
${ }^{11}$ By the late 1990's and early 2000's, the Coasean-Williamsonian branch had begun to win wider adherents as well, and both branches of NIE became well established. For specifics on NIE's diffusion see The Handbook of New Institutional Economics. The references provided in their different chapters substantiate the richness of analysis already available at the time the book was published. This can be completed by the collection of papers in Furubotn and Richter (1991), in the seven volumes by Ménard (2004b), in Brousseau and Glachant (2008), and in the synthesis already proposed by Furubotn and Richter (1997). See also partial surveys provided in Shelanski and Klein (1995), Klein (2005), Ménard (2004a).

${ }^{12}$ North's enormous impact on historical analysis is beyond the scope of this paper; indeed we cannot truly do justice to his huge impact on economics and other disciplines.
} 
societal institutions affect sector or locality rules and performance. ${ }^{13}$ Similarly, in law and economics, studies of how legal institutions frame market exchanges and investor incentives have ballooned since the 1980 's. ${ }^{14}$

North's ideas had an especially strong impact on development economists, practitioners in the aid community, and policy makers and scholars in developing countries. The collapse of planned economies opened a Pandora's box of choices, and scholars and practitioners alike seized on Northean institutional analysis to help inform these decisions. Scholars studying underdevelopment turned to North as one of the few prominent economists offering persuasive new answers to the question of why some countries are rich and some countries are poor. Starting in the mid-1990's the importance of institutions to development began to be increasingly accepted among development scholars and practitioners. North was first invited to speak at the World Bank in 1994, and spoke frequently to aid agencies, consulted with presidents and top officials of developing countries, and gave speeches to packed audiences in developing countries around the world. The World Bank devoted one of its flagship publications, the 2002 World Development Report, to institutions and development, and institutional issues were also taken up in many subsequent WDRs as well as in World Bank Policy Research Reports starting with Bureaucrats in Business (1995). Other international agencies soon adopted the same focus (see for example, InterAmerican Development Bank 2003, International Monetary Fund 2003, 2005). Interestingly, critiques of development assistance were also strongly influenced by North. These critiques cite the failure and

\footnotetext{
${ }^{13}$ See for example, Ostrom's work on common pool resources and case studies of local management; Levy and Spiller 1996 on telecommunicatons; Shirley, ed. 2002 on water supply and the chapter on regulation of public utilities by Spiller and Tommasi in the Handbook of New Institutional Economics.

${ }^{14}$ See for example, the several chapters on legal institutions in the Handbook of New Institutional Economics.
} 
even inability of foreign aid to deal adequately with institutional barriers to growth (see, for example, Easterly 2002, Martens et. al 2002, Shirley 2008). One reason for this apparently paradoxical influence was the tendency of some in the aid community to ignore those aspects of institutional analysis that conflicted with their belief that outside assistance can change institutions (see Shirley 2008 for examples).

The implications of Northean institutional analysis for growth also began to have a large impact on macro economists. So-called new growth economists increasingly included aggregate measures of institutions in Solow style growth models. Unlike the earlier frustrating experience of scholars who tried to correlate growth with democracy with often ambiguous results, these economists discovered that institutional variables had statistically strong, positive correlations with growth. These strong correlations led even some previously disdainful mainstream economists to use them in their own work. As one economist described the situation: "Growth economists who, as mentioned earlier, used to rely almost uniquely on pareto-optimal-complete-market-perfectly competitive neoclassical models, now systematically abandon their traditional paradigms without being ashamed and they discuss the role of institutions without thinking they are doing second-rate research" (Sala-i-Martin, 2002, p. 17, emphasis added). Furthermore, these “institutional” measures were easily accessible. For example, Knack and Keefer 1995, one of the earliest papers to use an aggregate measure of institutions in regressions and perhaps the one that launched this trend, used widely available commercial risk ratings as proxies for institutional quality. The subsequent upsurge in studies employing this and similar variables has been a mixed blessing, since the variables are abstract and general, 
running counter to NIE's emphasis on increasing realism and precision in economics. But they did spur wider interest in institutions among mainstream economists.

Initially most applied institutional analysis focused largely on formal, written institutions, neglecting North's emphasis on societal norms and beliefs. ${ }^{15}$ Among the few authors to defy this trend is Elinor Ostrom who emphasizes social norms in the success of community groups in managing common property. Avner Greif is another institutionalist who treats social norms seriously. For Greif, beliefs, norms, and organizations are as much a part of institutions as Northean rules. Indeed, for Greif, institutions are such powerful motivators precisely because they incorporate individuals' beliefs and internalized norms about the world, including their expectations of how others will behave and will expect them to behave. Like Ostrom, Greif is one of the small but growing number of institutionalists who do empirical work encompassing both Williamsonian transaction cost economics and Northean institutional analysis. (See for example, Greif 2006.) ${ }^{16}$

\section{Challenges}

As we have shown, research on NIE spread rapidly and the diffusion of the Northean branch was especially fast. But institutional analysis faces some major challenges for the future. One is to develop a satisfactory general theory of NIE that integrates Northean institutional analysis with Williamsonian transaction cost economics. A general theory would explain how the institutional framework (described by North as

\footnotetext{
${ }^{15}$ The same is true of econometric studies regressing growth on institutional variables. Of 59 such studies that were categorized by Shirley, only 6 dealt with informal institutions, specifically trust and social capital (Shirley 2005).

${ }^{16}$ Another example of this sort of synthesis can be found in the case studies of urban water reform in Shirley, 2002.
} 
the scaffolding for human transactions) interacts with the structure of governance (defined by Williamson as the matrix in which the integrity of a transaction is organized). This raises a lot of issues explored by Ménard 2006, issues that will likely shape much future research. A foremost issue would be: how do the (Northean) rules that determine the security and functioning of property rights or the laws that affect contractual credibility and enforcement shape the choice of (Williamsonian) modes of governance and of the ways to organize transactions? A related question is: what are the comparative costs of different institutional schemes, such as different judicial systems for implementing contractual laws?

Beyond this daunting challenge of bridging the gap between a society's general institutional framework and its specific transactions and modes of governance, there are also areas where institutional analysis needs to be developed further. North himself has challenged NIE to produce better theories, especially a theory of the state, and better explanations of growth and innovation. NIE needs a better theory of institutional change as well. Some aspects of current institutional theory make change seem almost impossible. North has long argued that change in deeply rooted institutions is fundamentally gradual and incremental (see for example, North 1990b). Change is gradual because long standing beliefs and conventions are usually slow to change, even though formal institutions can change rapidly in response to deliberate policies. North, Wallis, and Weingast 2009 also suggested that profound institutional change results from a long process of incremental changes that bring a society first to the "doorstep conditions" and finally to a "tipping point," when the society is transformed from limited to open access. This sets a much higher bar for institutional change then merely rewriting 
laws or even constitutions. Recent case studies applying this theory to a sample of limited access societies show progress in the complicated and difficult task of building a predictive theory. ${ }^{17}$ But it will be a challenge to document the historical roots of profound changes that appear to have happened quite rapidly, sometimes within the space of decades: consider Eastern Europe, Taiwan, or South Korea. Apparently abrupt change in informal institutions also presents a challenge to this theory. For example, the convention of foot binding in China, which had been practiced for millennia, was ended in a decade (Mackie 1996).

\section{Conclusion}

The future for NIE broadly and for institutional analysis specifically looks very bright. Acceptance and adherents continue to grow, and new research is pushing out the frontiers of the field. Indeed, one of the most daunting challenges for NIE is no longer to survive and prosper, but to maintain its revolutionary character and be open to good ideas from across disciplines without abandoning the powerful tools of economics. Further conceptual breakthroughs depend on rising to this challenge. It is true that crossdisciplinary work has drawbacks. The expansion of institutional analysis across the social sciences has resulting in a host of sometimes confusing and contradictory theories. Yet powerful partnerships have also emerged, for example, in political economy or in law and economics. One of the strengths of NIE is that is has not taken refuge in the arrogance of some schools of economics and isolated itself from the rest of the social and physical sciences. Here the three founding thinkers have led the way. They all have freely adopted from other fields: most notably, Coase from law, Williamson from managerial sciences

\footnotetext{
${ }^{17}$ Case studies using the North, Wallis, Webb, and Weingast framework (2009) have been done on Chile, Bangladesh, India, Mexico, Mozambique, Philippines, and Zambia under the auspices of the World Bank.
} 
and organizational theory, and North from political science, cognitive science, and history.

The increasing mainstream acceptance of new institutional economics may tempt some institutionalists to demand greater methodological orthodoxy which could stifle NIE's creativity. North stands as a living example against this danger; he continues to exemplify the revolutionary roots of NIE. As our brief summary of his work indicates, North's creativity has never ebbed and his research always seeks new frontiers. He has often been the first to challenge his own conclusions and has never let his past work become a hindrance in his search for radical new approaches. This has kept institutional analysis in the forefront, attracting new adherents in pursuit of new research directions.

\section{References}

Alchian, Armen A. 1965. "Some Economics of Property Rights". Il Politico, 30 (4): 816819. Reprinted in Economic Forces at Work (1977). Indianapolis: Liberty Press.

Barzel, Yoram. 1989/1997. Economic Analysis of Property Rights. Cambridge (UK): Cambridge University Press.

Brousseau, Eric and Jean-Michel Glachant (eds.). 2008. New Institutional Economics: A Guidebook. Cambridge (UK): Cambridge University Press.

Buchanan, James and Gordon Tullock. 1962. The Calculus of Consent: Logical Foundations of a Constitutional Democracy. Ann Arbor: University of Michigan Press.

1975. "A Contractarian Paradigm for Applying Economic Theory". American Economic Review. 65 (5): 225-230.

Cheung, Steven N. S. 1969. "Transaction Costs, Risk Aversion, and the Choice of Contractual Arrangements". Journal of Law and Economics, 13 (1) April, 23-42. . 1973. "The Fable of the Bees: An Economic Investigation." Journal of Law and Economics, 16 (1) April: 11-33.

1983. "The Contractual Nature of the Firm" Journal of Law and Economics, 26 (1) April: 1-21. 
Coase, Ronald H. 1959. "The Federal Communications Commission." The Journal of Law and Economics, 2:October, pp. 1-40. . 1960 "The Problem of Social Cost." The Journal of Law and Economics. 3: 144.

1988a. The Firm, the Market and the Law. Chicago: The University of Chicago Press.

. 1988b. "The Nature of the Firm (Originally Published in Economia, 4 (16)

November 1937)," in The Foundations of the New Institutional Economics.

Claude Ménard ed. Cheltenham, UK and Brookfield, VT, US: Edward Elgar, pp. 51-70.

. 1992. "The Institutional Structure of Production." The American Economic Review, 82:4, pp. 713-719.

Demsetz, Harold. 1967. "Toward a Theory of Property Rights". American Economic Review, 57 (May): 347-359.

Easterly, William. (2002). The Elusive Quest for Growth. Economists' Adventures and Misadventures in the Tropics. Cambridge, MA: MIT Press.

Furubotn, Eirik G. and Rudolf Richter. 1991. The New Institutional Economics. College Station (TX): Texas A \& M University Press.

1997. Institutions and Economic Theory: The Contribution of the New Institutional Economics. Ann Arbor, MI: The University of Michigan Press.

Greif, Avner. 2005. "Commitment, Coercion and Markets: The Nature and Dynamics of Institutions Supporting Exchange." In Ménard, C. and M. Shirley (eds), Handbook of New Institutional Economics, Springer, chap. pp. 727-786 2006. Institutions and the Path to the Modern Economy. Lessons from Medieval Trade. Cambridge, UK: Cambridge University Press.

InterAmerican Development Bank (2003). 'Modernization of the State, Strategy Document.' InterAmerican Development Bank: Washington, D.C.

International Monetary Fund (2003). World Economic Outlook, April 2003: Institutions and Growth. Washington, D.C.: International Monetary Fund.

(2005). World Economic Outlook, September 2005: Building Institutions. Washington, D.C.: International Monetary Fund. 
Klein, Peter G. 2005. "The Make-or-Buy Decisions: Lessons from Empirical Studies." In C. Ménard and M. Shirley (eds.), Handbook of New Institutional Economics, Berlin: Springer. Chap. 17: 435-464.

Knack, Stephen, and Philip Keefer. 1995. "Institutions and Economic Performance: Cross-Country Tests Using Alternative Institutional Measures." Economics and Politics 7(3):207-27.

Levy, Brian and Pablo Spiller. 1996. Regulations, Institutions and Commitment. Comparative Studies of Telecommunication. Cambridge: Cambridge University Press.

Mackie, Gerry. 1996. "Ending Footbinding and Infibulation: A Convention Account " American Sociological Review, 61:6, pp. 999-1017.

Martens, Bertin, Uwe Mummert, Peter Murrell, and Paul Seabright (2002). The Institutional Economics of Foreign Aid. Cambridge: Cambridge University Press.

Ménard, Claude.2004a. "The Economics of Hybrid Organizations", Journal of Institutional and Theoretical Economics, 160 (3): 345-376 (ed).2004b. The International Library of New Institutional Economics. Cheltenham UK): Edward Elgar Publisher. 7 volumes 2006. "Challenges in New Institutional Economics." in U. Bindsell, J. Haucap and C. Wey (eds.), Institutions in Perspective, Tubingen: Mohr-Siebeck, pp. 2133

Ménard, Claude and Mary Shirley. 2010. "From Intuition to Institutionalization: A History of New Institutional Economics." Paper presented to the annual meeting of the International Society for New Institutional Economics, Sterling, Scotland.

Ménard, Claude and Mary Shirley (eds.). 2005/2008. Handbook in New Institutional Economics

North, Douglass C. 1961. The Economic Growth of the United Staes 17901860.Englewood Cliffs, N.J.: Prentice-Hall, Inc. 1966 Growth and Welfare in the American Past. A New Economic History. Englewood Cliffs, N.J.: Prentice-Hall, Inc. . 1968. "Sources of Productivity Change in Ocean Shipping, 1600-1850." The Journal of Political Economy. 76 (5) pp. 953-970. 1981. Structure and Change in Economic History. Cambridge [UK]: Cambridge University Press. 
.1990a. Institutions, Institutional Change, and Economic Performance. New

York: Cambridge University Press.

. 1990b. "A Transaction Cost Theory of Politics." Journal of Theoretical Politics

2(4): 355-367.

. 1993. "Douglass C. North, the Sveriges Riksbank Prize in Economic Sciences in Memory of Alfred Nobel 1993: Autobiography." Vol. 2010. The Nobel

Foundation.

. 1994. "Economic Performance through Time." American Economic Review, 84, pp. 359-68.

2005. Understanding the Process of Economic Change. Princeton: Princeton University Press.

North, Douglass C and Lance Davis. 1970. Institutional Change and American Economic Growth.

North, Douglass C. and Robert Paul Thomas. 1973. The Rise of the Western World: A New Economic History. Cambridge, U.K.: Cambridge University Press.

North, Douglass C. and Barry R. Weingast. 1989. "Constitutions and Commitment: The Evolution of Institutions Governing Public Choice in Seventeenth-Century England." The Journal of Economic History, 49:4.

North, Douglass C., John J. Wallis, and Barry R. Weingast. 2009. Violence and Social Order: A Conceptual Framework for Interpreting Recorded Human History. New York: Cambridge University Press.

North, Douglass C., John J. Wallis, Steven B. Webb, and Barry R. Weingast. 2009."Limited Access Orders: Rethinking the Problems of Development and Violence." Unpublished working paper, June 8, 2009.

Sala-i-Martin, Xavier. 2002. "15 Years of New Growth Economics: What Have We Learnt?" Columbia University. 25 p.

Shelanski, Howard and Peter Klein. 1995. «Empirical Research in Transaction Cost Economics: A Survey and Assesment» Journal of Law, Economics and Organization, 11 (2) : 335-361

Shirley, Mary M. 2005. "Institutions and Development," in Handbook of New Institutional Economics. Claude Ménard and Mary M. Shirley eds. Dordrecht, The Netherlands: Springer, pp. 611-638.

. 2008. Institutions and Development. Cheltenham, UK and Brookfield, VT, US: Edward Elgar. 
. ed. 2002. Thirsting for Efficiency: The Economics and Politics of Urban Water System Reform. Oxford: Elsevier Science.

Weingast, Barry R. 1993. "Constitutions as Governance Structures: The Political Foundations of Secure Markets." Journal of Institutional and Theoretical Economics (JITE), 149:1, pp. 286-311.

Williamson, Oliver E. 1.1971. "The Vertical Integration of Production: Market Failure Considerations." $\quad$ American Economic Review, 61 (May): 112-123

1975. Markets and Hierarchies: Analysis and Antitrust Implications. A Study in the Economics of Internal Organization. New York: Free Press. 1996. The Mechanisms of Governance. Oxford: Oxford University Press.

Woolf, Virginia. 1928. Mr. Bennett and Mrs Brown, London: Hogarth Press

World Bank (1995). Bureaucrats in Business. Washington DC.: Oxford University press

World Bank. (2002). World Development Report 2002: Building Institutions for Markets. Washington, D.C.: Oxford University Press 
Figure 1: Early Roots of North's Ideas

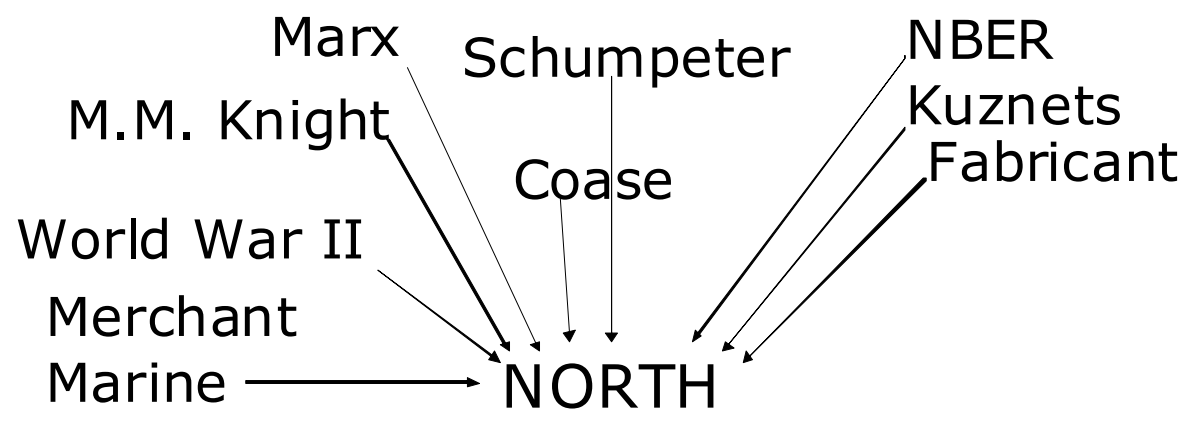


Figure 2: North's Evolving View of Institutions as Reflected in his Major Publications

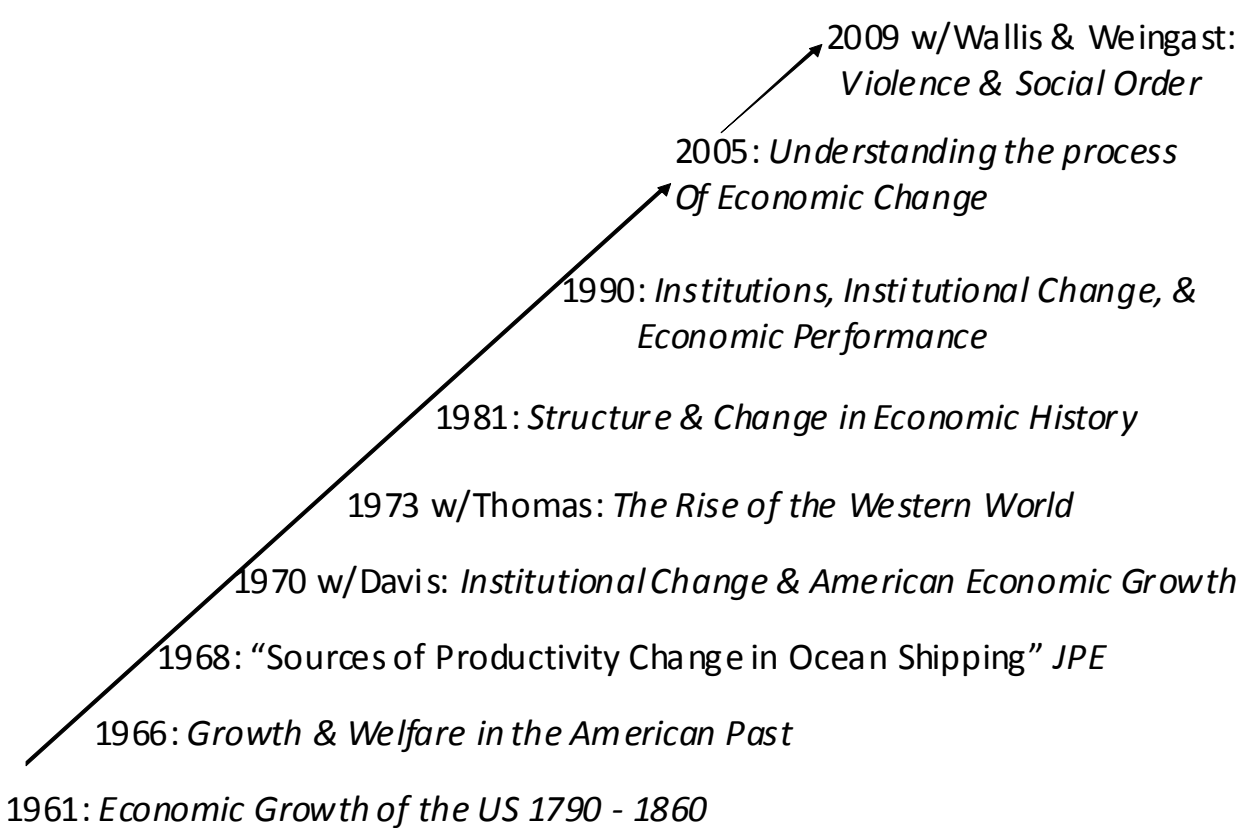

1961: Economic Growth of the US 1790 - 1860 
Figure 3: Citations of North's Articles

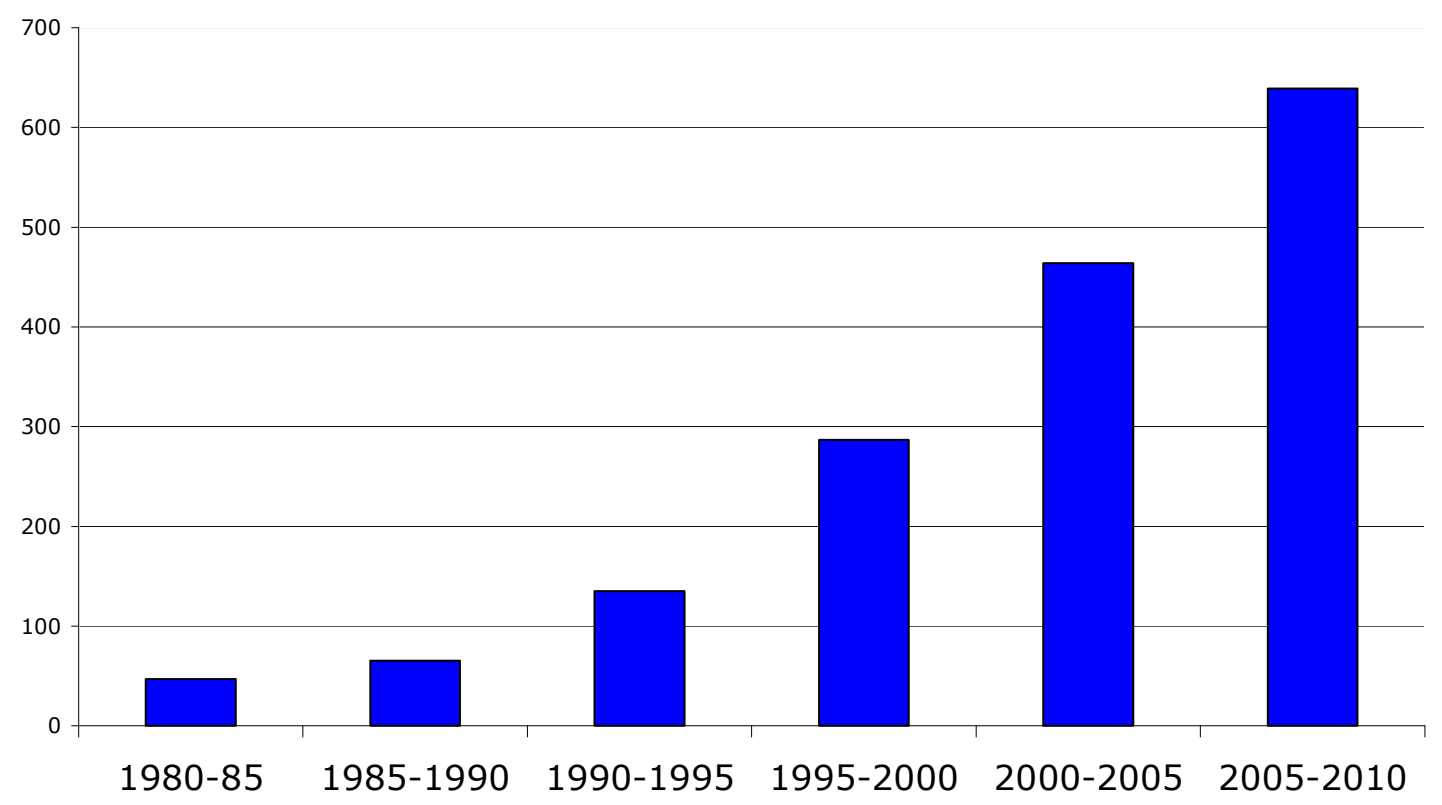

Source: Web of Science. 
